\title{
Effectiveness of Developed Instructional Module on the Enhancement of Learners Academic Achievements in Physics
}

\author{
Cherry Rose T. Malgapo \\ Aliaga National High School, Senior High School Department \\ Nueva Ecija, Philippines \\ cherryrosemalgapo@gmail.com
}

Abstract - The study examined the effectiveness of developed instructional module on the enhancement of learners' academic achievements specifically this current situation of COVID-19 pandemic under distance learning delivery modalities. This instructional module in Physics was personally developed by the researcher and intended to used in teaching-learning process in Senior High School under the Department of Education. The participants of the study are the grade 12 SHS students at Aliaga National High School into two groups -the controlled and experimental. The parameters are the content knowledge, alignment to learning competencies, learning tasks, assessment method, design course, friendliness and timeliness. To examine the effectiveness, the experimental research designed was employed. The following findings were made: the mean pre-test scores of two groups had 5.40 and 5.33 which means almost the same while the post-test mean scores of controlled group had 14.40 and experimental group had $\mathbf{1 7 . 8 0}$ which means the mean scores of experimental group were higher than the mean scores of the controlled groups. The pretest of two groups of participants had value of 14.976 with significant value of .000 and found out "not significant" while the post-test had value of 14.976 with significant value of .000 and interpreted as "significant" therefore the developed instructional module in Physics found "effective" and had impact to students' academic performance. On the assessment made on the effectiveness of developed instructional module in Physics the overall weighted mean got 3.77 with an interpretation of "Very Satisfactory". Continuous development and enhance of instructional module is recommended.

Keywords - instructional module, effectiveness, learning competencies, Physics

\section{INTRODUCTION}

Development of instructional material plays a vital role in the enhancement of academic achievement of the learners in all learning areas. There are lots of learning materials that the learners could be used, but limited to that can easily understand at their own paced especially this trying times of COVID-19 pandemic. Because of no face-to-face classes, learners had experienced struggles and difficulties to learn and teachers as well in the distance learning modalities. Thus, the role of instructional module in learners' progress is very crucial.

According to Portana et.al (2021), the developed instructional materials can be classified as primary and secondary aids and outlines used in effective teaching and learning. Hence, it is the ability of the teachers to 
identify the quality and appropriateness upon utilizing the developed instruction materials. And on students' part, instructional materials may guide them to acquire more information so as to bring the learners much appreciation on the topics under consideration.

Not all learning materials like books are available in bookstores, in online library and even in other open access library portal. Thus, not all are suitable to the individual differences and preferred learning styles of the students.

Additionally, Onyedikachi (2011) as cited in the study of Oden (n.d), teaching without tools is impossible to attain the teaching and learning goals and competency. The instructional tools spice up the teaching and learning process to make possible on better understanding and make students learn from themselves.

Furthermore, Onasanwa and Omosewo (2011), discussed instructional materials as a key component that may used in teaching and learning process that can disseminate information, data, idea and messages that could help learners enhance their academic achievements.

The researcher aims to determine the effectiveness of personally developed instructional module in Physics on the enhancement of learners' academic achievements specifically this current situation of COVID19 under the context of distance learning delivery modalities.

\section{OBJECTIVES OF THE STUDY} Physics.

The study aimed to examine the effectiveness of the personally developed instructional module in

The study sought to answer the following:

1. Describe the performance of two groups-controlled and experimental in terms of pre-test and posttest.

2. Describe the significant differences between the results of pre-test and posttest of two groups of participants.

3. Describe the parameters used in testing the effectiveness of personally developed instructional modules in Physics in terms of content knowledge, alignment to learning competencies, learning tasks, assessment method and design course.

\section{RESEARCH METHOD}

The researcher used the experimental descriptive research design involving 30 grade 12 SHS students and grouped into two equal numbers of participants- controlled and experimental and were selected using matching technique. The instruments used were the pre-test and posttest with 10 to 20 items test questions and assessment questionnaires for the testing and assessing parameters. The controlled group used any available modules while the experimental group used the developed instructional module in Physics which was personally developed by the researcher herself. The Pre-test was given before the lesson-discussion proper and posttest after the lessondiscussion. And for the assessment of instruments it was distributed before the end of the semester, only those who used the instructional modules (experimental group). 
Figure 1 shows the paradigm of the study.

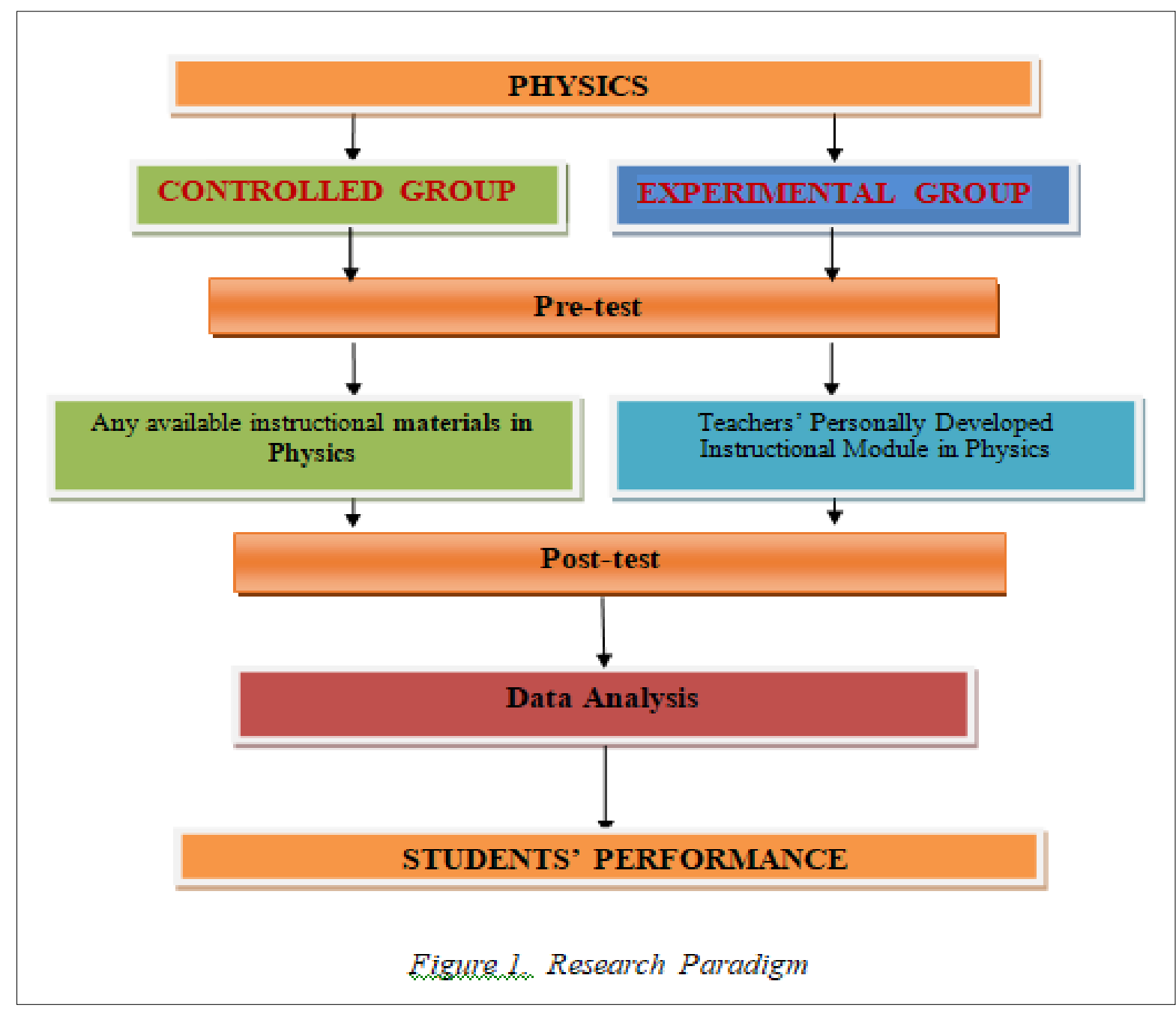

And the questionnaire consisted of Likert scale with verbal description of "Excellent", "Very Satisfactory", "Satisfactory", "Below Satisfactory" and "Poor" as choices. The same way that the equivalent description to be "Extremely Effective", "Very Effective", "Moderately Effective", "Less Effective", and "Not Effective".

Range of scores and its verbal interpretation is shown below:

Table 1. Range and Verbal Interpretation Equivalent

\begin{tabular}{|c|c|c|c|}
\hline Point & Range & Verbal Analogy & Effectiveness Verbal Equivalent \\
\hline 5 & $4.21-5.00$ & Excellent & Extremely Effective \\
\hline 4 & $3.41-4.20$ & Very Satisfactory & Very Effective \\
\hline 3 & $2.61-3.40$ & Satisfactory & Moderately effective \\
\hline 2 & $1.81-2.60$ & Below Satisfactory & Less effective \\
\hline 1 & $1.00-1.80$ & Poor & Not effective \\
\hline
\end{tabular}




\section{RESULTS AND DISCUSSION}

1. Descriptions of the performance of two groups-controlled and experimental in terms of pre-test and posttest.

Table 2. Student-Participants Pre-test and Post-test

\begin{tabular}{|l|l|c|c|}
\hline \multicolumn{2}{|c|}{} & \multicolumn{2}{|c|}{ PHYSICS } \\
\hline \multirow{2}{*}{ C } & \multicolumn{1}{|c|}{ Tests } & Mean & Sd \\
\cline { 2 - 4 } N & & & \\
T & Pre-tests & 5.33 & 2.895 \\
R & & & \\
O & & & \\
L & & 14.40 & 1.920 \\
E & Post-tests & & \\
D & & & \\
\hline E & & 5.40 & 3.418 \\
X & & & \\
E & Pre-tests & & \\
R & & & \\
I & & & \\
M & & & \\
E & & & \\
N & Post-tests & & \\
T & & & \\
A & & & \\
\hline
\end{tabular}

Table 2 shows the results of pretest and posttest of two groups of students-participants. As shown, the mean pre-test scores of two groups had 5.40 and 5.38 which means almost the same while the post-test mean scores of controlled group had 14.40 and experimental group had 17.80 which means the mean scores of experimental group were higher than the mean scores of the controlled groups. The results implied that the scores of the same sets of student-participants in the same competencies were evidently improving using developed instructional module in Physics that those in the controlled group with the used of any available instructional materials. Meaning to say the student-participants were performing after the used of personally developed instructional modules. The students can easily understand the topics in the personally developed instructional module than other available instructional materials in Physics.

2. Description of the significant differences between the results of pre-test and posttest of two groups of participants.

Table 3. Pre-test and Post-test

\begin{tabular}{|l|c|c|c|}
\hline ANOVA & $\boldsymbol{F}$ & $\begin{array}{c}\text { Significant } \\
\text { Value }\end{array}$ & Interpretation \\
\hline Pre-test Control and Experimental & 0.748 & .389 & $\mathrm{NS}$ \\
\hline Post-test Control and Experimental & 14.976 & .000 & $\mathrm{~S}$ \\
\hline
\end{tabular}

Legend: S - Significant; NS - Not Significant 
As shown in table 3, the pre-test of the controlled and experimental groups had f-value ).748 with significant value of .389 and interpreted as "Not Significant" while the post-test of the same groups had f-value of 14.976 with significant value of .000 and interpreted as "Significant". The result implies that pretest of controlled and experimental groups had no significant differences while the post-test, there were significant differences. This means, the students perform better in Physics with the used of personally development instructional module in Physics than those who used any available instructional materials. The personally developed instructional module are suited to the learning capability and level of understanding of the studentparticipants especially this trying times of distance learning due to COVID-19 pandemic.

3. Descriptions on the parameters used in testing the effectiveness of personally developed instructional modules in Physics in terms of content knowledge, alignment to learning competencies, learning tasks, assessment method and design course.

Table 4 shows the assessment of the parameters used in testing the effectiveness of personally developed instructional module in Physics. As shown the assessment made on the effectiveness of developed instructional module in Physics the overall weighted mean got 3.77 with an interpretation of "Very Satisfactory". The content knowledge had mean of 4.72 and learning task had 4.23 both interpreted as "Excellent" with verbal descriptions of "Extremely Effective" alignment to learning competencies, and assessment method got the highest weighted mean of $4.72,4.70 \& 4.65$ respectively with verbal description "Extremely Effective" while alignment to learning competencies and design course had mean of 3.89 and assessment method had 3.43, all are interpreted as "Very Satisfactory" with verbal descriptions of "Very Effective". Thus, friendliness and timeliness had mean of 3.35 and 3.23, respectively and interpreted as "Moderately Effective".

Table 4. Parameters on the effectiveness of personally developed instructional module in Physics

\begin{tabular}{|l|c|c|}
\hline \multicolumn{1}{|c|}{ Description } & Weighted Mean & Verbal Description \\
\hline Content Knowledge & 4.72 & Excellent \\
\hline Alignment to Learning Competencies & 3.89 & Very Satisfactory \\
\hline Learning Task & 4.23 & Excellent \\
\hline Assessment Method & 3.48 & Very Satisfactory \\
\hline Design Course & 3.89 & Very Satisfactory \\
\hline Friendliness & 3.10 & Satisfactory \\
\hline Timeliness & 3.05 & Satisfactory \\
\hline Overall Weighted Mean & $\mathbf{3 . 7 7}$ & Very Satisfactory \\
\hline
\end{tabular}


The results depicted that personally developed instructional module in Physics is very effective for the students to have a better understanding on the lessons/topics. The students can easily finish the learning task provided in the module. This connotes that developed instructional materials in physics can satisfy the needs of diverse learning even under the distance learning delivery modality. It is also designed as to individualized instructions that the students learned at their own paced.

\section{CONCLUSION AND RECOMMENDATIONS}

Conclusion

The following conclusions are drawn:

a. The post-test mean scores of controlled group had 14.40 and experimental group had 17.80 which mean that the mean scores of experimental group were higher than the mean scores of the controlled groups. The results implied that the scores of the same sets of student-participants in the same competencies were evidently improving using developed instructional module in Physics.

b. The post-test of the same groups had f-value of 14.976 with significant value of .000 and interpreted as "Significant". The students can easily understand the topics in the personally developed instructional module than other available instructional materials in Physics.

c. On the assessment made on the effectiveness of developed instructional module in Physics the overall weighted mean got 3.77 with an interpretation of "Very Satisfactory". The results depicted that personally developed instructional module in Physics is very effective for the students to have a better understanding on the lessons/topics. The students can easily finish the learning task provided in the module

Recommendations

a. Teachers and experts in the field continuously developed instructional module in more simplest and easiest way in all learning areas for the diverse learning.

b. School administration, school head may fund and support teachers in developing instructional materials and send teachers to different training workshop purposely for instructional module development.

\section{ACKNOWLEDGEMENT}

With God as the main source of abundant blessings, the researcher wishes to express her heartfelt gratitude and appreciation to those who are in one way or another contributed to the completion of this study. To her family, friends, colleagues and co-workers, thank you so much for all the support and encouragement. 


\section{REFERENCES}

[ 1]. Portana, H. V., Fronda, J.G., Policarpio, D.G.T., Rome, C. R., \& Lllames, G.A. (2020). Effectiveness and Acceptability of Instructional Materials in the Enhancement of Students' Academic Achievement. International Journal of Advanced Engineering Management and Science, 7(1),12-15-2021.https://doi.org/10.22.161/ijaems.71.2

[2]. Oden, C. (n.d). The Effectiveness of Instructional Materials in Teaching and Learning of Biology in Senior Secondary School. Retrieved from: https://www.projecttopics.org/effectiveness-instructional-materials-teaching-learning-biology-seniorsecondary-school.html

[3]. Onasanya, S.A. and Omosewo, E.O. (2011). Effect of improvised and standard instructional materials on Secondary School Students' Academic Performance in Physics in Ilorin, Nigeria. Retrieved from: https://scialert.net/fulltext/?doi=sjsres.2011.68.76

[4] Ezekoka, M. A. (2008). Teaching Materials and Students Academic Achievements. Proceedings of the $43^{\text {rd }}$ Annual Conference of STA 7-416-419. Ibadan:Heinemann

[5] Koko, M.N. (2016). The Effective Use of School Instructional Materials. Retrieved from: file:///C:/Users/ITZ\%20SHAR/Downloads/THEEFFECTIVEUSEOFSCHOOLINSTRUCTIONALMATERIALSAutosaved.pdf

[6] Koko, M.N. (2015). Teaching Business. Port Harcourt, Nigeria: Harvey Publication Company.

[7] Soetan, A.K., Iwokwagh, N.S., R.A. Shehu, and Onasanya, S.A. (2010). Creating engaging 3-D animation digitization for instructional media and communication. Inform.Technol. J., 9: 89-97.

[8] mAlice, O. (2012). Challenges facing the teachers and students in the of instructional technologies: A case of selected secondary schools in KISII Country, Kenya Retrieved from:https://irlibrary.ku.ac.ke/bitstream/handle/123456789/6532/Omariba\%20Alice.pdf?sequence=3 